\title{
The Paradox of Ipseity and Difference: Derrida's Deconstruction and Logocentrism
}

Roland Theuas S. Pada

\section{Deconstruction and Repetition}

I

$\mathrm{n}$ thinking of Derrida's notion of deconstruction as an attitude in understanding logocentrism, one might find it necessary to pre-empt this discourse by taking into serious consideration three words: center, consciousness, and difference. These words offer the key towards the problem of logocentrism within Derrida's deconstruction and, as far as these words seem to contextualize themselves within Derrida's texts, they also offer an explanation of how meaning becomes possible. Derrida's deconstruction is a form of writing in which the "I-ness" of the self is given emphasis as both the limitation and possibility of appropriation in so far as context is concerned. Reading for him is already considered as an act of writing, the text, being polysemic in its inscription, already implies that the repetition of the syntax of words will always be rendered by the consciousness with a relative amount of impurity. Every instance of reading then is a form of writing, each time an Other tries to read the singularity of the construction of the text, it is already altered as another occurrence within another consciousness.

Deconstruction alters what it concerns itself with. This is made apparent by most of Derrida's works, and to be particular, his deconstruction of the speech act theory. ${ }^{1}$ In dealing with Austin's texts, Derrida's position was questioned by Searle, accusing him of misinterpreting Austin on several grounds, ${ }^{2}$ one of which is on Derrida's insistence to include parasitic speech acts as a condition of the iterability of a text or even that of language itself, primarily because communication already implies a set of rule bound axioms that would, by itself, make the intentions of a speaker known to its interlocutor. ${ }^{3}$ In his response, Derrida explains that parasitism is a condition in which texts become iterable, precisely because the transference of meaning is already operating in between the similarity and differences of the consciousness

1 Cf. Jacques Derrida, Limited Inc., trans. by S. Weber and J. Mehlman, (Evanston Illinois: Northwestern University Press, 1988).

2 Cf. John Searle, "Reiterating the Differences: A Reply to Derrida," in Glyph I (1977), 198-208.

${ }^{3}$ Ibid., 199. 
of the author and its recipient, ${ }^{4}$ which he aptly refers to as the economy of difference. 5 Elsewhere, he also considers this economy to be the general system of similarity and difference taken as a singular account existing within the transaction between the self and its other, ${ }^{6}$ it is an economy in which the text extends itself further in its repetition of itself through an other, and with it the limitations of its extensions becomes implied as it expands to the extents of its new iteration. The entirety of this activity for Derrida is already deconstructive. There are various ways of defining or rather, describing the operations of deconstruction: one of which is passive and the other is active. Both however, subscribes towards the alteration or the parasitism in which the contamination of the text is implied, for in a passive deconstruction, the "reader" merely applies the content of his or her bias in accordance to the structure of the text itself. The active variant of deconstruction, on the other hand, is a teasing out of contradictions within the interplay of the text of an author's work and its claims of presence; in seeing this contradictions within the text, the "reader" (or more fittingly, the writer) inserts his or her criticisms and alterations of the work, radically altering the text within its own enclosures and within the limits of the "reader's" understanding of the text. Derrida's works would usually fall into the second variant of deconstruction, for his criticisms involves an internal dissection of another author's work itself, 7 which contrary to what critics would call "skeptical," helps the discourse move further in the direction of its goals.

Both of these variants of deconstruction concern themselves with the problem of repetition ${ }^{8}$ and, in both cases, deconstruction has always subscribed to the economy of différance as far as repetition is concerned. In Dissemination, Derrida accounts for repetition as a severance from "good writing," to which he comments Plato's notion of writing:

\footnotetext{
${ }^{4}$ Derrida, Limited Inc., 74.

5 Derrida would write this in the context of the transaction of identities made between the "I" and the "Other" in Levinas' Totality and Infinity. Jacques Derrida, "Violence and Metaphysics," in Writing and Difference, trans. by A. Bass, (London: Routledge, 1978), 129. 1981), 8-9.

${ }^{6}$ Jacques Derrida, Positions, trans. by A. Bass, (Chicago: University of Chicago Press,

7 To note, Derrida's deconstructive method is keen enough to observe a certain standard of rigor. Derrida's deconstructions are often made on the account that he has read not only the work in question, but also the works of such authors and the other authors involved in the text. For example, in reading Levinas, Derrida takes as a context the entirety of the philosophemes involved with Levinas (i.e. Heidegger, Husserl, Judaism, Kierkegaard, etc.), and not only this proves most of his points as sound and well thought of, it also opens the discourses that he deconstructs to further exploration and even application.

8 Derrida employs several motifs that refers to repetition in which the effect of differance becomes apparent. Among such motifs is the notion of mimesis and Mallarme's mimodrama in Dissemination, in which the mime never really repeats the originary scene of the scene, but rather, recreates the scene with some relative sense of verisimilitude while at the same time retaining the unique taint of the mediation of an individuals 'miming' of scene or the 'appearing. The paradox that belongs to mimesis or repetition involves the indeterminable congruency and dissimilutation that exists in the relation of the copy from that of the original.
} 


\section{THE PARADOX OF IPSEITY AND DIFFERENCE}

... writing is determined within a problematic of knowingremembering. It is thus from the start stripped of all its own attributes or path-breaking powers. Its path-breaking force is cut not by repetition but by the ills of repetition, by that which within repetition is doubled, redoubled, that which repeats repetition and ins so doing, cut off from "good" repetition (which presents and gathers being within living memory), can always, left to itself, stop repeating itself. Writing would be pure repetition, dead repetition that might always be repeating nothing, or be unable spontaneously to repeat itself, which also means unable to repeat anything but itself: a hollow, cast-off repetition. ${ }^{9}$

One will say then that Derrida, in this passage, is not actually against Plato but, rather, is in agreement with him. If "good repetition" were to be considered to be good, then one might as well adduce that such a repetition is able to bring back presence as it was. However, the case is that presence is always already lost within the experience of the consciousness: in place of this presence is a mediated ersatz of its original, a copy that is a dead repetition of presence to which one might refer to as memory. In saying this, memory is already thought of in Derrida's works as a representation of presence, it is the originary logos that imparts telos to the text.

The repetition then of the logos is in part affected by memory. As an Other, for example, tries to read this text, that Other is in part recalling his or her own memory of what these symbols and signifiers signify, and in part, they are also looking at the syntax of my work as it plays along in its own symmetry so as to disclose my intentions to their own consciousness. As a consequence of this occurrence of the mediation of consciousness towards an Other, the alterity or différance $e^{10}$ of each and every singularity that is the ego, affects the purity of repetition. In repeating these words in the consciousness of Others, the purity of my intentions begins to be blurred, if not totally erased. To recall Derrida's notion of writing under erasure, ${ }^{11}$ this situation shows that to write under erasure means that the present impetus of what appears and is present during the

\footnotetext{
${ }^{9}$ Jacques Derrida, Dissemination, trans. by B. Johnson (Chicago: University of Chicago Press, 1981), 135. [My emphasis]

10 This is to retain the sense of difference and ipseity existing within the uniqueness or subjectivity of an individual's own apperception of the Other and vice versa. To note, Levinas notion of alterity suggests an absolute aporetic fear of reduction, to which an affective manifestation of the face of the Other becomes an unfathomable imperative command. Derrida deconstructs Levinas' position on ethics by pointing out Levinas' aversion towards ontology as an internal limitation of the ethics of alterity by acknowledging the inevitable helplessness of ethics in the absence of ontology. Despite this, one would later on find several distinct traces of Levinasian ethics within Derrida's latter works on ethics but only on the context of succumbing to alterity through the exhaustion of difference.

11 Jacques Derrida, Of Grammatology, trans. by G. Spivak, (Baltimore: The John Hopkins University Press, 1997), 60.
} 
inscription is efface or erased by writing as representation. What I am writing at this moment would, in its purity, be lost in the differences of the state of consciousness in which an Other would read this, and even to myself, as my consciousness becomes altered through time, and thus lose my old self or my old state of consciousness.

In this regard, one could say that I am writing in anticipation of my future disappearance, for in reading this once more, I have become an Other myself. Thus, in thinking of my future disappearance (which has always already occurred a while ago), I am under the effect of differrance, for in this moment I am similar to what I would be in the future, and at the same time, be different from what I am right now. Derrida's neologism, differance, ${ }^{12}$ in itself, already demonstrates ipseity and at the same time difference. For in its inscription, on one hand, it intends to break away from its past, as Derrida states, from the phonocentric tendency of language: on the other hand, it still retains its similarity with the French word difference, retaining the remnants or the traces of the very same system that it tries to move away from.

In what follows, I will attempt to explore the three key elements in the function of repetition, namely: center, consciousness, and difference. It is in this explication that I would base my contextualization of Derrida's varying notions of logocentrism and, in turn, point out that within deconstruction, logocentrism becomes an imperative of its operation. My aim is to clarify what is implied in Derrida's critique of logocentrism and to expose an apparent contradiction in his critique. This would serve as the foundation upon which we can discuss the possibility of an ontology that would best describe the operation of Derrida's deconstruction.

\section{The Alterity of the I}

In Derrida's reading of Husserl in Speech and Phenomena, Derrida tells us that the meaning of language lies in its telos,,$^{13}$ the goal of which is to make something present in the consciousness of the other through expression and sign (bedeuten und sinn). The problem lies, however, in the discrepancy between one consciousness and another, for despite the intention to signify and express something, language remains somewhat detached from the internal sphere of indication from the ego. ${ }^{14}$ There is always an element in which meaning from expression and sign, differs from the original intention of a consciousness, for in so far as the text (or expression) aims at signifying, it already manifests the

12 Différance differs from difference or the French "Difference" not only through its spelling but also with its intended meaning. It is the retention of both the structure and meaning of the word 'difference' and at the same time the effacement of its own meaning for differance stands for the phenomenological and structural difference and ipseity of a subject's inscription from that of the object of its miming or repetition. Jacques Derrida, Margins of Philosophy, trans. by A. Bass (Chicago: University of Chicago Press, 1982), 16.

13 Jacques Derrida, Speech and Phenomena, trans. by D. Allison (Evanston Illinois: Northwestern University Press, 1973), 36.

${ }^{14}$ Ibid. 


\section{THE PARADOX OF IPSEITY AND DIFFERENCE}

non-presence of the living present ${ }^{15}$ or différance. Suffice to say that in communication, there is a certain form of absence in so far as it does not fully express the intention of the ego towards its other. Words only indicate presence, they are by themselves an indication that what is being signified is no longer present. When I listen to another, his lived experience is not present to me "in person," 16 and it is in this way that we come to understand that we are different from the Other, and that our familiarity with the Other's ego is limited.

This sense of absence and indeterminability is what Levinas would refer to as the infinity behind the Other ${ }^{17}$ that provides us with the compelling justification to have an ethical responsibility of participating in the project of the other because the Other's infinity impels us through our inability to know them as an inviting mystery for further epistemic investigation. We can find a different way of expressing this Levinasian notion of ethics in Derrida's reading of Levinas, though Derrida disagrees with some major points in Totality and Infinity, he nonetheless subscribes to the ethics of undecidability. One might consider Derrida's ethics to have taken its root in Levinas' notion of fecundity, ${ }^{18}$ wherein the undecidability or the indeterminate nature of the Other's alterity is taken as an ethical framework of non-violence, whereas violence is considered as a manifestation of subjectivity towards the other. Derrida's revision of this ethical system is done through the integration of differance as an epistemic transaction or a mode of calculation in which knowledge is tested so as to provide the possibility of subjectivity through a pre-ethical establishment of Otherness in the ego of the subject. ${ }^{19}$ This economy is, for Derrida, a necessary violence, so as to enable the I to surrender itself in the call of the face, which gives rise to an impoverishment of the ego to participate in the fecundity of the Other. Since the actual "murder" of the Other does not actually occur, but rather only within the subjectivity of the I, Derrida thinks that the entire fear of reduction of the Other is a laughable "self-evident but criminal truism" which inevitably places ethics under the "heel of ontology." 20

In dealing with Levinas' ethics, one becomes aware that Derrida still remains faithful to the priority of ontology as the fundamental mode of knowing or talking about Being. Suffice to say, that Derrida finds Levinas inevitably going back to the priority of ontology despite his claim of endowing ethics such priority. ${ }^{21}$ The ego then ought to be considered essentially as a

\footnotetext{
${ }^{15}$ Ibid., 37.

16 Ibid., 38.

${ }^{17}$ Emmanuel Levinas, Totality and Infinity, trans. by A. Lingis, (Pennsylvania: Duquesne University Press, 1969), 213-214.

18 Cf. Emmanuel Levinas, Time and the Other, trans. by R. Cohen, (Pennsylvania: Duquesne University Press, 1987), 90-94.

${ }^{19}$ Derrida, Writing and Difference, 128.

${ }^{20}$ Ibid., 135.

${ }^{21}$ Levinas would say: "History would not be the privileged plane where Being (Sein) disengaged from the particularism of points of view (with which reflection would still be affected) is manifested. If it claims to integrate myself and the other within an impersonal spirit this alleged integration is cruelty and injustice, that is, ignores the Other." Levinas, Totality and Infinity. p.52
} 
subjectivity that gives rise to difference, but only to the extent that one does not consider the I or the Other as a monad, or as a purely exterior ${ }^{22}$ entity. It would help to find the words through Hegel, just as what Derrida did in his reading of Levinas, ${ }^{23}$ in order to illustrate the importance of self-consciousness as an epistemological framework in which the ontology of difference becomes established through ipseity:

Self-consciousness exists in itself and for itself, in that, and by the fact that it exists for another self-consciousness; that is to say, it is only by being acknowledged or "recognized." The conception of this its unity in its duplication, of infinitude realizing itself in selfconsciousness, has many sides to it and encloses within it elements of varied significance. Thus its moments must on the one hand be strictly kept apart in detailed distinctiveness [difference], and, on the other, in this distinction must, at the same time, also be taken as not distinguished [ipseity]. ${ }^{24}$

Hegel answers the problem between ipseity and difference through a dialectic of intersubjectivity which can be deemed as the encounter between the I and the Other. It does not however, mean that the ego is shaped merely by its subjectivity, for in the beginning of a consciousness' throwness into the world, it begins its knowledge of the self as an acknowledgment of otherness and of the Other's acknowledgment of the I-ness of the subjectivity that tries to participate with its being through an encounter. Hornedo notes this possibility of dialectic interaction between the self and the Other:

Having admitted the reality of dialectic interaction between the self (more vulgarly to be called the individual subject), it is not difficult historically to demonstrate how individuals create objective reality and history while at the same time being created by them through his own agency

22 My use of the word exteriority connotes an internality that does not lend its immanence towards transcendence. On the contrary, Derrida might support the notion that the ego or the subjectivity is external to Others, but then to consider this as pure or as a total condition of the subjectivity would then erase the possibility of intersubjective relations. Just as in the case of Levinas, the recourse towards an ethics of pure difference leads one to conclude that the "I" and the "Other" would be totally indifferent from each other since they would not be able to even acknowledge the Otherness of one other. I will clearly object with the point that the ego is a conatus, only because its interiority is affected by its exteriority. Thus, the "Other," despite its exteriority, is still accessible to an " $\mathrm{I}$ " in as much as it manifests its interiority externally, and hence affects an Other interiority (which is the "Other's" exteriority) that is also an Other. Through participation, the difference of the "I" and the "Other," is no longer considered to be pure in so far as there is a convergence of "selves" occurring in their encounter.

${ }^{23}$ Cf. Derrida, Writing and Difference, 140.

24 G.W.F Hegel, Phenomenology of Mind, trans. by J.B. Baillie (New York: Dover Publications, Inc., 2003), 104-105. [My interpolations] 


\section{THE PARADOX OF IPSEITY AND DIFFERENCE}

by action and reaction. The case cannot be the classic sophism of the so-called "chicken-and-egg" pseudo paradox. The logic here is not casually linear but social. It does not presume to start with singularity. It starts with givenness, the presumption of facticity and therefore historicity. 25

The dialectical interaction, then, occurs as a given condition of the ego; the world itself lends the possibility of encountering the Other, by shaping the consciousness of the subjective ego, they are able to meet in a context that allows them to acknowledge ipseity and difference through intersubjectivity. The self then is not an enclosed consciousness but, rather, it is an openness that creates itself through its encounter of the Other in time and space. This encounter, however, does not lend itself towards a harmonic convergence of consciousness, for in most cases the dialectical encounter between two consciousness involves differences in which Hegel would refer to as sublation ${ }^{26}$, or as Derrida would say, a necessary economy of violence or différance. ${ }^{27}$ The condition however of subjectivity is inevitable, for in the context of "there-ness" or even that of the "there is," time assaults the ego to reduce the Other as an object, and in this regard, Derrida would say that the "I" is not actually guilty of committing violence against the other because time is violence ${ }^{28}$ itself.

The problem of the exteriority and interiority of the ego, however, is not the only problem that concerns subjectivity. For in its being-in-the-world, the ego is always already engaged in manifesting itself to an Other and, as Hegel would say, this manifestation of the self is always subjected towards "elements of varying significance" that affect the presentation of a self towards an Other. Thus, in the intention of manifesting itself towards an Other, the forces that act upon the self already contaminate the ego's manifestations, and hence the possibility of failure towards the acknowledgment of the Other comes as a consequence of its presence as a fleeting singularity. In the essay Signature Event Context, Derrida notes that the grounds in which the consciousness is able to manifest its intention to express itself is always contaminated, not as an excluded accidental possibility, but as the very means of language itself in its repetition through an Other. ${ }^{29}$ The problem of context for Derrida, reveals that

${ }^{25}$ Florentino Hornedo, Pagpapakatao (Manila: University of Santo Tomas Publishing House, 2002), 56.

26 "...Self-consciousness has before it another self-consciousness; it has come outside itself. This has a double significance. First it has lost its own self, since it finds itself as an other being; secondly, it has thereby sublated that other, for it does not regard the other as essentially real, but sees its own self in the other.

It must cancel this its other. To do so is the sublation of that first double meaning, and is therefore a second double meaning. First, it must set itself to sublate the other independent being, in order thereby to become certain of itself as true being, secondly, it thereupon proceeds to sublate its own self, for this other is itself." Hegel, op cit., 105.

${ }^{27}$ Derrida, Writing and Difference, 128.

28 Ibid., 133.

${ }^{29}$ Cf. Derrida, "Signature Event Context," in Limited Inc, 12. 
the exchange of intentions are always governed by an economy of ipseity and difference, or what he calls différance. 30 The repetition of the word or the text, always implies a parasitica ${ }^{11}$ interference of the consciousness in the absence of what the text signifies. Thus, despite the assumption of taking a central point of convergence in the encounter of the "I" and the "Other," the center is affected not only by its fluctuations within time and space, but also to the relative congruency in which it conforms to the subjectivity of the ego.

In the search for meaning from Otherness, we find ourselves in an epistemological quagmire. For in deconstruction, there is an assumption that the effacement of its claims of purity of presence is done from within, and yet in Derrida's claims of an irreducible interiority and exteriority, one sees that it is impossible to distinguish the two primarily because the distinction itself, as Derrida would say, is arbitrary. ${ }^{32}$ How would one then be able to efface logocentric claims, if one cannot determine a logocentric tendency within the text itself? In this case, a re-evaluation of Derrida's notion of logocentrism should be commenced in order to properly assess the limitation of ontology or metaphysics in its assumption of presence. Thus, we must put the center into question.

\section{The Eccentric Center of the Logos}

The logos, as the Greeks would understand it, is the reason or the meaning of Being, it is the very determination of ideas in which meaning is made possible, it is also at the same time the telos of signs that governs the very movement in which a grapheme may take in its iteration. Like phonocentrism, ${ }^{33}$ logocentrism supports "the determination of presence of the being of the entity as presence. ${ }^{34}$ The problem however with logocentrism or any other form of centrism, as Derrida's interpretation of the Austinian notion of context itself would present, is that it is eccentric; it changes from one context to another, primarily because it can never be understood in purity. The effacement of the claims of presence then in a text, or even that of a speech act is riddled with the problem of consistency in its repetition. Derrida notes this problem in $O f$ Grammatology:

The movement of deconstruction do not destroy structures from the outside. They are not possible and

${ }^{30}$ Ibid., 18-19.

31 This term connotes the contamination of the author's intention to mean something in an expression or an utterance. Austin uses this term to connote the unconventional use of a statement to express otherwise what was intended by the words (or the author) himself. Cf. J.L. Austin, How to Do Things With Words, ed. J. Urmson and M. Sbisá (London, Oxford University Press, 1975), 22. In Derrida, this is seen as a graft, in which the text, gains a new form of meaning by its introduction towards a different context. Cf. Derrida, Limited Inc, 12, 80-82.

32 Derrida, Of Grammatology, 44.

33 This implies the preference for speech over writing with regard to the immediacy of presence.

${ }^{34}$ Derrida, Of Grammatology, 12. 


\section{0}

\section{THE PARADOX OF IPSEITY AND DIFFERENCE}

effective, nor can they take accurate aim, except by inhabiting those structures. Inhabiting them in a certain way, because one always inhabits, and all the more when one does not suspect it. Operating necessarily from the inside, borrowing all the strategic and economic resources of subversion from the old structure, borrowing them structurally, that is to say without being able to isolate their elements and atoms, the enterprise of deconstruction always in a certain way falls prey to its own work. This is what the person who has begun the same work in another area of the same habitation does not fail to point out with zeal. No exercise is more widespread today and one should be able to formalize its rules. ${ }^{35}$

To recall the earlier distinctions made on logocentrism, Derrida indirectly implies the problem that is incurred within the notion of logocentrism itself. For on one hand, the unconscious or the passive way of inhabiting the text occurs as a zealous way of asserting a formal and pure sense of meaning that the text manifests; on the other hand, the active sense of logocentrism sees logocentrism as an invitation to inhabit the text for what it has to manifest, excluding, for the mean time, the imposed canonical notions of how the text itself should operate. The problem with logocentrism, as I have mentioned earlier, is that it is a mere supplementation of a lost presence, and in dealing with this eccentric center, one does not actually know the totality of the intention of what the text tries to manifest towards its recipient (be it towards an intended recipient or not).

As a consequence of convenience, language creates this problem of giving the center the character of permanence, viz., the written logos. The center, moreover, is always already differing from itself upon its inscription. History, for example, is problematic, because the experience and the inscription of the events in time are unique in their appropriation; ${ }^{36}$ thus, there is a difference between the historian's experience of an actual event (based on this very own account) and what his readers would understand from the same account. Thus, one will see that the logos is double-edged, it conveys the no longer present for the convenience of others who were not there, while, at the same time, it obfuscates the account of presence that was once there. In Derrida's reading of Plato in Dissemination, Derrida would agree with Plato's notion of writing as a supplement or as a pharmakon. ${ }^{37}$ As a supplement introduced to the

35 Ibid., 24.

36 Ibid., 20.

37 "There is certainly play in such a movement, and this chiasmus is authorized, even prescribed, by the ambivalence of the pharmakon. Not only by the polarity good/evil, but by the double participation in the distinct regions of the soul and the body, the invisible and the visible. This double participation, once again, does not mix together two previously separate elements; it refers back to a same that is not the identical, to the common element or medium of any possible dissociation." Derrida, Dissemination, 127. 
body, the pharmakon is both at the same time a medicine and a poison, to an internality, ${ }^{38}$ whose moral value remains ambiguous in so far as the intention of the body who uses it is indeterminate. By indeterminacy, I imply that the pharmakon's definition holds up to its ambivalence, ${ }^{39}$ precisely because its introduction towards the body is done from the outside. One then, looks at representations, particularly the text, as an externality that supplements the ego or the self in its inability to make present a lost moment in its totality. Derrida, would only disagree with Plato's notion of the pharmakon as a supplement, with regards to its exclusion as an impurity. Derrida notes this in his citations of Plato's dialogues:

The immortality of a living being would consist in its having no relation at all with any outside. That is the case with God. God has no allergies. Health and virtue, which are often associated in speaking of the body and, analogously, of the soul, always proceed from within. The pharmakos is that which, always springing up from without, acting like the outside itself, will never have definable virtue of its own. ${ }^{40}$

This claim of internal purity will somehow be questionable with regards to the epistemic validation of the certainty of the body of knowledge, for in stating that the inside must be pure from the outside, one already espouses a solipsism of some sort. The contamination of the center is always inevitable or, in other words, it is always already occurring. For example, to all the accounts of Derrida cited in this text, one might say that I have merely contaminated the discourse on deconstruction itself. But is it really pure? To begin with, deconstruction focuses its own discourse on an eccentric center. One might say that deconstruction "originated" from the sixth section of Heidegger's Being and Time, or even that of its dismantling of Saussure's linguistic structuralism, but to all these claims, one can be assured that Derrida's discourse is always already contaminated. This always already recurs not as a mere gesture of assurance that what is being said is truthful, but as an acknowledgment that my work, or even Derrida's work, cannot be severed from its historicity. In other words, the purity of the discourse is a myth, for if it were to survive, or even be inscribed through its own self as its center, discourse itself would have become impossible.

One might think that Derrida's notion of logocentrism is aporetic, for in its impossibility of pure repetition, one finds oneself referring to nothing. If the logos of the text is no longer there, where then does the text refer to? To answer this, Derrida refers us back to the traces themselves. The problem with

\footnotetext{
38 Ibid., 97-98.

39 By ambivalence, I mean that the pharmakon retains its meaning, while its value remains indeterminate in as far as its "goodness" or its "badness" is dependent upon the effect of its introduction to an internality.

${ }^{40}$ Derrida, Dissemination, 101-102.
} 


\section{THE PARADOX OF IPSEITY AND DIFFERENCE}

presence is that in its evanescence its immediacy is lost within time itself. However, despite its fleeting nature, presence, leaves its traces behind, and these traces itself, constitutes the parts and intentions of such presence, which leaves us with some partial clues to reconstruct, and bring the lost presence through supplementation:

The unheard difference between the appearing and the appearance (between the "world" and "lived experience") is the condition of all other differences, of all other traces, and it is already a trace. This last concept is thus absolutely and by rights "anterior" to all physiological problematics concerning the nature of the engramme [the unit of engraving], or metaphysical problematics concerning the meaning of absolute presence whose trace is thus opened to deciphering. The trace is in fact the absolute origin of sense in general. Which amounts to saying once again that there is no absolute origin of sense in general. The trace is the differance [différance] which opens appearance [l'apparaitre] and signification. Articulating the living upon the nonliving ideal than real, not more intelligible than sensible, not more a transparent signification than an opaque energy and no concept of metaphysics can describe it. And as it is a fortriori anterior to the distinction between regions of sensibility, anterior to sound as much as to light, is there a sense in establishing a "natural" hierarchy between the sound-imprint, for example, and the visual (graphic) imprint? The graphic image is not seen and the acoustic image is not heard. The difference between the full unities of the voice remains unheard. And, the difference in the body of the inscription is also invisible. ${ }^{41}$

In this long passage from Of Grammatology, one will see why Derrida is having some difficulty in expressing his notion of trace as both the presence and non-presence, primarily because traces are examples of presence and non-presence. Appearing and appearance already lends itself as a clue, or perhaps, a trace of what Derrida intends to convey, for appearing is different and, at the same time, similar to what appearance would convey. Appear-ing indicates a verb in the present progressive form, meaning that it is in the constant state of presence, indicating a constant temporal movement and not a fixed hypostatized condition. On the other hand, appearance differs from appearing, in so far as it is a noun that indicates an impression of an object, and thus a hypostatized state in which an object is thought to be $i n$. In relation to this, the trace is something that is appearing, and understood as an appearance. The difference is given emphasis by Derrida as an epistemic condition; for in our intention to perceive what is

${ }^{41}$ Ibid., 65. 
appearing, we tend to consider that appearing as appearance. In this distinction, one apprehends that traces are both appearing and appearance rolled under into a unit of singularity. Traces are, on one hand, part of the appearing (thus connoting, partial presence), and on the other, a residue of appearance (for it is considered to be a signifier of an author's memory [signification] of presence that signifies another presence, ad infinitum). As this complicates itself under the lenses of my own consciousness, one may look at the direction in which Derrida makes his double gesture in his description of the trace, it is at the same time, the absolute origin of sense and the absolute origin of non-sense. Sense here is an equivocal term that requires distinction, before anything else is understood. The trace is the thing that we perceive to be there, it is the thing that is appear-ing before us. Hence, it is not the absolute origin of rationale or sense, in other words, it cannot be the absolute source of rationale or comprehension, primarily because the trace is already a mediated presence of what is perceived to be appear-ing. It must be understood that by invoking the words sense and non-sense, I am implying a formal distinction between the sensible and the non-sensible, to which I find the necessity of introducing another long passage, with the promise of clarity rather than obscurity. Hence, we call upon Merleau-Ponty's Sense and Non-Sense:

The germ of universality or the "natural light" without which there could be no knowledge is to be found ahead of us, in the thing where our perception places us, in the dialogue into which our experience of other people throws us by means of a movement not all of whose sources are known to us. Metaphysics begins from the moment when, ceasing to live in the evidence of the object - whether it is the sensory object or the object of science [metaphysics] - we apperceive the radical subjectivity of all our experience as inseparable from its truth value. It means two things to say that our experience is our own: both that it is not the measure of all imaginable being in itself and that it is nonetheless co-extensive with all beings of which we can form a notion. This double sense of the cogito is the basic fact of metaphysics: I am sure that there is being - on the condition that I do not seek another sort of being than being-for-me. When I am aware of sensing, I am not, on the one hand, conscious of my state and, on the other, of a certain sensuous quality such as red or blue - but red or blue are nothing other than my different ways of running my eyes over what is offered to me and of responding to its solicitation... Metaphysics is the deliberate intention to describe this paradox of consciousness and truth, exchange and communication, in which science lives and which it encounters in the guise of vanquished difficulties or failures to be made good but which it does not thematize. From the moment I recognize that my experience, precisely insofar as it is $m y$ 


\section{THE PARADOX OF IPSEITY AND DIFFERENCE}

own, makes me accessible to what is not myself, that I am sensitive to the world and to others, all the beings which objective thoughts placed at a distance draw singularly nearer to me ... Metaphysical consciousness has no other objects than those of experience: this world, other people, human history, truth, culture. But instead of taking them as all settled, as consequences with no premises, as if they were selfevident, it rediscovers their fundamental strangeness to me and the miracle of their appearing. ${ }^{42}$

To go back to Derrida, we can see that by stating that there is no absolute origin of reason or comprehension (sense) because the trace is the absolute origin of sense (perception), we understand that by talking about the presence of a sensory object and that of a metaphysical one, we are always already invoking a radical subjectivity that is inseparable from its truth value itself. Thus, the appearing is the trace of the appearance itself and, as far as Derrida is concerned, the subjectivity imbued upon this remnants of presence, is inseparable in so far as it is the very thing that appears to us. Merleau-Ponty notes this as the paradox of subjectivity itself, for in understanding Derrida's notion of the trace, we are left to think of it as a singular instance of an empirical reality or singularity, that is in itself a rendition of an Other's perception of the appearing as an appearance. The trace becomes the origin of absolute sense in so far as it is the only thing that we can encounter, and suffice it to say, in its deficiency, make something actually present (since it is already a trace of a trace), it proves to us (in the context of the text) that it is not the absolute source of sense in general..$^{43}$ Thus, generally speaking, the trace is a sensible unit of meaning, in so far as it is the only connection to the presence that is always already lost. Thus, in looking at Derrida's notion of the trace through Merleau-Ponty's notion of perception and its relation to metaphysics, one might say that the visible or the audible becomes invisible and inaudible in so far as it always already apperceived by the consciousness, and as a result sense (perception) becomes non-sense (metaphysics). The trace then, leaves one to ponder on Heidegger's question of the distinction between Be-ing and beings (Da-sein und das-seindes), and in this pondering between these distinction, one will imagine Derrida positing the question itself of différance on Heidegger's question: why is it that we need to make a distinction between Be-ing and beings in the first place?

\footnotetext{
42 Maurice Merleau-Ponty, Sense and Non-Sense, trans. by Hubert and Patricia Dreyfus (Illinois: Northwestern University Press, 1964), 93-94. [My emphases and interpolation]

43 At this point one must be able to notice that the trace implied by Derrida varies polysemically in its application. On the one hand, it might refer to another trace itself, and, on the other, it might also refer to an actual presence. But in either case, Derrida would consider the consciousness to be treating both as an actual empirical reality or singularity as it is simulated by language (or any form of representation) itself. As a consequence, however, the verifiability of the trace remains obscured for the reason that it is already an imprint or a representation of what took place in time.
} 


\section{The Differing Difference of Ipseity}

In seeking the center in which deconstruction tries to unsettle, one finds that the answer lies on Derrida's notion of difference or, specifically, differance. Différance is the ontology of ipseity and difference that explains the entire activity of the repetition in which logocentrism is used as an eccentric center. The intention of this neologism is to show the function of ipseity and difference under one singular activity in which meaning is transferred and inscribed. As I have stated earlier, this neologism is a movement away from the original towards the Other, while at the same time retaining its old self. This neologism itself is based on various philosophemes and even psychoanalytic themes that express the simultaneous activity of ipseity and difference. Derrida would, for example, refer to Nietzsche in terms of his writing style, as an activity of moving against the different forces that has controlled or even dominated metaphysical grammar, without abandoning the very language in which these forces imposes upon philosophical discourse. ${ }^{44}$ Freud, also, was used as an example of how the ego, in its instinct for self-preservation, moves into reality without abandoning the intentions of the ego of obtaining pleasure for itself, thus retaining its selfhood and at the same time moving towards others as its means of acquiring pleasure $^{45}$ [Jouissance]. Derrida would even go as far as using différance as an explanation of how the consciousness of the self in Hegel engages in a dialectical encounter with its other to obtain its own self-consciousness through sublation or Aufhebung [or in French, as Derrida would translate, la reléve]. ${ }^{46}$ The most common and obvious example, however, is his alteration of the word difference to différance. ${ }^{47}$

The difference in spelling is a blatant defiance of Saussurean linguistics, wherein the valorization of speech over writing is done due to the immediacy of speech over writing, which Saussure finds important primarily because of the semiotic capability of speech to phonetically distinguish one word from another. ${ }^{48}$ To put Saussure's claim into irony (which Derrida takes seriously), Derrida's modification of the letter $e$ in différence provides a mockery of Saussure's position that words are distinguished from one another phonetically, for in its pronunciation, différance, does not have any phonetic difference from difference. ${ }^{49}$ What is notable about this demonstration of the

\footnotetext{
${ }^{44}$ Derrida, Margins of Philosophy, 18.

45 Ibid., 19.

46 Ibid.

47 Ibid., 3-4.

${ }^{48}$ Ferdinand de Saussure, Course in General Linguistics, trans. by R. Harris, ed. C. Bally and A. Schehaye (Illinois: Open Court Publishing Company, 1983), 23-24.

49 “. . . But I would say that this in itself - the silence that functions within only a socalled phonetic writing - quite opportunely conveys or reminds us that, contrary to a very widespread prejudice, there is no phonetic writing... from this point of view, that the difference marked in the "differ ()nce" between the $e$ and the $a$ eludes both vision and hearing perhaps happily suggests that here we must be permitted to refer to an order which no longer belongs to sensibility. But neither can it belong to intelligibility, to the ideality which is not fortuitously affiliated with the objectivity of theorein or understanding. The order that resists the opposition,
} 


\section{THE PARADOX OF IPSEITY AND DIFFERENCE}

activity of differance is its essential erasure and retention of metaphysics. The logos in which différance operates and erases the transaction of reference, to which the signifier finds itself transposed as a signified, can be likened to what Heidegger would refer to as the essential swaying of being, in which the inquiry towards "correctness" is put against an ontological lagging that serves as an impetus to respond towards the distress of the absence of presence in the signification of Being. 50

In différance, we see an opportunity for epistemic contextualization rather than an abyss of nothingness. Derrida opines that différance ought to be understood as an activity of differing/deferring,, 51 in which the fundamental grounding of the history of onto-theology is deferred and differed. ${ }^{52}$ To understand this, we must go back to Derrida's gesture of writing under erasure. To write under erasure is to efface the sign and at the same time retain the sign under its effacement. Derrida, as Spivak notes, borrows this gesture from Heidegger's crossing out of the word "Being" as a sign of the inarticulability of Be-ing, ${ }^{53}$ whereas, in contrast to Saussure's claims of the sign arbitration of what it signifies, Derrida crosses out the copula "is" 54 for it connotes an arbitrary deferral that forgets the essential differing of the subject. The point of emphasis towards difference is that its inclusion within the act of deferring should not be taken absolutely, and this is also applicable towards the seemingly endless referral of signifier towards another signifier. To write under erasure means the retention and the effacement of the origin in writing. Hence, one would recall that trace being a residue of presence is essentially retained as its origin.

One has to be wary of this statement. As a caution it can be recalled that Derrida does not entirely deny the originary, the source, or the object, rather, what he denies is the possibility of a full retrieval of the absolute origin ${ }^{55}$ in which the determination of writing becomes determined even in its inception. Derrida will even go as far as stating that différance itself is an arbitrary nomination of an activity that can never be named which, despite this, is referred to as différance merely as a nominal provision. ${ }^{56}$ Significations, as it is revealed and written towards its interlocutors are instantaneous singular occurrences of differance. As I project in my thoughts the various orders of the words that I have to write to signify my memory of my sense of Derrida's discourse, I become engaged in referring from my memory the discourse in which I have already perceived and made sense out of. The traces that I recall in

one of the founding oppositions of philosophy, between the sensible and the intelligible. The order which resists this opposition, and resists it because it transports it, is announced in a movement of différance (with an a) between two difference or two letters, a différance which belongs neither to the voice nor to writing in the usual sense." Derrida, Margins of Philosophy, 4-6. ${ }^{50}$ Martin Heidegger, Contributions to Philosophy (On Enowning), trans. by K. Maly and P. Emad, (Indianapolis, Indiana University Press, 1999), 229-230.

${ }^{51}$ Derrida, Of Grammatology, 23.

52 Ibid.

53 Translator's Preface, Of Grammatology, xvii.

${ }^{54}$ Ibid.

55 Derrida, Of Grammatology, 65.

${ }^{56}$ Derrida, Margins of Philosophy, 26. 
memory, are always already an impression of how Derrida's texts play against my self-consciousness, of how deconstruction operates; they are already sublated form of knowledge, in which I once more defer and concur in inscribing these impressions into another form of medium. When I read this discourse, I am then again detached or severed from the text, for it will appear to me once more with a sense of its own radical difference with regard to a future state of consciousness. ${ }^{57}$ This state of referring and deferring would continue to occur, not only with me, but also towards the others who will try and read this work. Though my proximity towards the work itself lends me the access towards most of its nuances of meaning. I can reconstruct the traces that would itself mark the traces that I have assembled to remind me (and others) of how my scathingly fleeting thoughts arranged themselves when I have, at one moment in time, sensed that my understanding of Derrida's work (or traces) have become congruent. My old self has already disappeared. These traces then that I see (or shall see later on) are merely markers of my state of consciousness at one point in time, they will lead me (whenever I look back at them) towards a reconstruction of my immediate past disappearance, and to some extent convey my old intentions with some level of congruity with the differences that my new state of consciousness has or will have.

One finds, then, that the radical difference that what differance conveys is temporal. Evidence in Derrida's text would actually support this claim and it is quite necessary to call upon it in dealing with the problem of temporality:

Since the trace is not a presence but the simulacrum of $a$ presence, that dislocates itself, displaces itself, refers itself, it properly has no site - erasure belongs to its structure. And not only the erasure which must always be able to overtake it (without which it would not be a trace but an indestructible and monumental substance), but also the erasure which constitutes it from the outset as a trace, which situates it as the change of site, and makes it disappear in its appearance, makes it emerge from itself in its production. The erasure of the early trace (die frühe Spur) of difference is therefore the "same" as its tracing in the text of metaphysics. This latter must have maintained the mark of what it has lost, reserved, put aside. The paradox of such a structure, in the language of metaphysics, is an inversion of metaphysical concepts, which produces the following effect: the present becomes the sign of the sign, the trace of the trace. It is no longer what every reference refers to in the last analysis. It becomes a function in a

57 To prove this point, this work is already subjected towards multiple revisions to which the separation of my instances of singularities is made apparent by my mistakes and my revisions towards such mistakes. 


\section{THE PARADOX OF IPSEITY AND DIFFERENCE}

structure of generalized reference. It is a trace, and a trace

of the erasure of the trace. 58

Hence, the trace, as a marker of the repetition of singularities in its erasure, is the preservation of presence through metaphysics. It is an unavoidable recourse to what was present that leads us to utilize a very limited sense of presence. The text then, of metaphysics, is comprehended, ${ }^{59}$ restored, not in its original purity, but nonetheless restored to its possibility of coming into consciousness, both as an other and at the same time an ipseity of the trace of the trace.

One will also say then, without absolute finality, that we can opt that the trace, in its fleeting state of referring and deferring, is the very concept of radical absence itself, an absence that can haunt the present. In its essential haunting, it transforms itself, like the ouroboros, constantly consuming itself to become other than itself. Differance is the activity that occurs within the reading/writing of the trace. It is the economy that opens the range of possible recurrence of the trace in time, offending its past, and at the same time its future in order to make the present come into the fore of our thoughts in the fleeting singularity of time. ${ }^{60}$

\section{Towards the Possibility of an Ontology of Singularity}

It is, for Derrida, not impossible to speak of reality in its essential différance. Logocentrism as an essential foundation of episteme becomes a model of singularity in which knowledge is anchored upon. We cannot make things meaningful without the center for in our attempt to communicate thoughts and express our sense of reality (extra-mental or otherwise), we are always already at the mercy of time in its fleeting presence and absence. Derrida's point is that we should take the logos as a center for differing and referring singularly, and in this singularity that eludes us, we are always doing deconstruction actively and passively. ${ }^{61}$ The movements of time and space will always sway our consciousness of reality; and in this swaying we are advised by Derrida to take reality as a singularity occurring within the folds of time and space. Our search for the elusive and polymorphic signified is not in vain, since it was always already been there, as traces. One then will be able to say that there was really something behind the text, but in saying what that thing is, is something that we cannot really answer with absolute certainty. The traces of the signified, that is also essentially a signifier, is not simply Derrida's method, is not a game of playing tag in which

${ }^{58}$ Ibid., 24.

${ }^{59}$ Ibid.

${ }^{60}$ This is in allusion to Nietzsche's Zarathustra.

${ }^{61}$ In the espousal of ipseity and difference within the operation of deconstruction, one realizes that the mediation of one's subjectivity will always already be at work within the act of representing the representation of consciousness. Thus, in a reading or an interpretation of a text or object, one never really reads the same representation as it was intended by its author, what would be had is merely an innovated or even an ersatz of a trace that becomes the further erasure of the trace. 
we could never catch the presence of the signified, but that of a profession of a future that has yet to come. Each occurrence in time and space is unique, despite its similar recurrence from the past; it will always remain to be essentially different in the future (l'avenir).

Derrida's logocentrism is the very logocentrism that he tries to efface, and I will not make any distinction between them. To write under erasure is in itself différance in action. Derrida's position is not at all absurd, it is in fact hovering between the thinkable and the unthinkable, for in his intention of effacing the claims of purity in presence and absolute correlation of the sign towards its signified is actually fulfilled in the very margins of his discourse. The claim of differance is already the claim made by the actions of deconstruction, it claims to be different and, at the same time similar to its center, whose eccentricity spirals in the moment of its inception back towards its past and forward towards the future. It does indeed work from within, but only towards a constructed interiority of a representation. It will inhabit, dwell, and try to become enmeshed in the work itself. Despite this, however, deconstruction will always differ from what it defers. The limitations of time and space itself works as a promise of tomorrow, a bope for the others to come, Derrida speaks of this in the final paragraphs of his essay Différance:

From the vantage of this laughter and this dance, from the vantage of this affirmation foreign to all dialectics, the other side of nostalgia, what I will call Heideggerian bope, comes into question. I am not unaware how shocking this might seem here. Nevertheless I am venturing it, without excluding any of its implications, and I relate to it to what will seems to me to be the metaphysical part of "The Anaximander Fragment": the quest for the proper word and the unique name. Speaking of the first word of Being, Heidegger writes: "The relation to what is present that rules in the essence of presencing itself is a unique one, altogether incomparable to any other relation. It belongs to the uniqueness of Being itself. Therefore, in order to name the essential nature of Being, language would have to find a single word, the unique word. From this we can gather how daring every thoughtful word addressed to Being is. Nevertheless such daring is not impossible, since Being speaks always and everywhere throughout language." 62

The occurrence of Being is not supposed to be taken as a nibilism of some sort. We may, at its essential sway, be lost to its movements, yet the ability to speak of Being is never rendered impossible. We are not at the end of meaning itself or aporia; we are at the limits in which we encounter the ineffable

${ }^{62}$ Ibid., 27. 


\section{THE PARADOX OF IPSEITY AND DIFFERENCE}

experience of differance. We are, thus, invited to participate and encounter the very reality that is signified by language. And despite of the limitations of our way of speaking about Being, we must dare to speak about Being.

The very impetus of speaking about Being is justified by Derrida as an enduring project of participation and encounter. Our limitation is our singularity and the appearance of which, should be taken not as a source of frustration, but as an invitation. Indirectly, I think that Derrida is implying the possibility of speaking about beings in their absolute ipseity and difference. It is in this regard that we might see the possibility of constructing an ontology based on the singularity of presence. Being occurs as itself and, at the same time, different from itself.

Deconstruction is a way of looking at the immanent and transcendent reality behind texts. There is always an interplay between the elements of immanence and transcendence in so far as the in-itselfness of the object or the text is mediated by the transcendent state of the subject's consciousness. This condition is in fact deconstructive and, as far as Derrida and his predecessors are concerned (Hegel, Husserl, Heidegger, Nietzsche, etc.), this is the condition of knowledge itself. Things appear to us as instances of singularities, they are always appear-ing, and we are always taking them as an appearance. Deconstruction itself is logocentric, but it differs with other type of reading or interpretation, in so far as it acknowledges the fact that all forms of reading are always contaminated by the consciousness' mediation of its object. To look at reality as a singularity is to look at it with a sense of limitation and openness. Limitation in the sense that we are aware of the fact that the totality of what appears to us is in fact concealed. We have to realize that through openness we can further unwrap the mysteries of Being's coming-to-be, by participating in its activity of unveiling itself towards us. The epoch of logocentrism, for Derrida, is not merely the distress for the lack of distress for the question of Being, it is also essentially an invitation to participate in Being. By referring to Being and by effacing Being, we become the keepers and heirs of our father's fathers, Derrida is suggesting an active participation in which we affirm ourselves and those who were there before us, not by mourning the monuments which the dead has erected, but by honoring these monuments and erecting new ones over them.

\section{College of Accountancy, University of Santo Tomas, Philippines}

\section{References}

Austin, J.L., How to Do Things With Words, ed. J. Urmson and M. Sbisá (London: Oxford University Press, 1975).

Derrida, Jacques, Dissemination, trans. by B. Johnson (Chicago: University of Chicago Press, 1981).

Limited Inc. trans. by S. Weber and J. Mehlman (Evanston Illinois: Northwestern University Press, 1988). Margins of Philosophy, trans. by A. Bass (Chicago: University of Chicago Press, 1982). 


\section{R. PADA 51}

Of Grammatology, trans. by G. Spivak (Baltimore: The John Hopkins University Press, 1997).

, Positions, trans. by A. Bass (Chicago: University of Chicago Press, 1981).

, Speech and Phenomena, trans. by D. Allison (Evanston Illinois: Northwestern University Press, 1973).

, Writing and Difference, trans. by A. Bass (London: Routledge, 1978).

Hegel, G.W.F., Phenomenology of Mind, trans. by J.B. Baillie (New York: Dover Publications, Inc., 2003).

Hornedo, Florentino, Paspapakatao (Manila: University of Santo Tomas Publishing House, 2002).

Heidegger, Martin, Contributions to Philosophy (On Enowning), trans. by K. Maly and P. Emad (Indianapolis: Indiana University Press, 1999).

Levinas, Emmanuel, Time and the Other, trans. by R. Cohen (Pennsylvania: Duquesne University Press, 1987).

Totality and Infinity, trans. A. Lingis (Pennsylvania: Duquesne University Press, 1969).

Merleau-Ponty, Maurice, Sense and Non-Sense, trans. by Hubert and Patricia Dreyfus (Illinois: Northwestern University Press, 1964).

Saussure, Ferdinand de, Course in General Linguistics, trans. by R. Harris, ed. C. Bally and A. Schehaye (Illinois: Open Court Publishing Company, 1983).

Searle, John, "Reiterating the Differences: A Reply to Derrida," in Glyph I (1977), 198-208. 